\title{
Utilizing collaborative works: an attempt to enhance learners' participation in English class
}

\author{
Asis Wahyudi ${ }^{1}$, Dian Arsitades Wiranegara ${ }^{2}$, Bagus Putra Krisdiana ${ }^{3 *}$ \\ Universitas Islam Negeri Maulana Malik Ibrahim Malang; Jl. Gajayana 50 Malang, Tel. (0341)551354 \\ e-mail: *11wahyudi.asis@gmail.com, ${ }^{2}$ dwiranegara@gmail.com, ${ }^{3}$ bagus_english@yahoo.com
}

Keywords:

Collaborative works, learners' participation, action research, observation.

\begin{abstract}
A B S T R A C T
This action research project aimed to improve the participation of learners in the class of General English. Collaborative activities were designed by grouping learners to work with the assigned tasks. The data were collected through observation. The findings showed that the participation of learners increased greatly, characterized by the involvement of all learners in more active participation through group discussions and presentations of their works. In the attempt to disseminate our teaching experience, this article mainly focuses on the practical implementation of our collaborative action that is aimed to encourage other teachers and practitioners to implement the same research to improve their practices.
\end{abstract}

\section{INTRODUCTION}

Teaching and learning using a learner-centered approach have been popular because it gives access to learners to gain progress. In this way, active participation is crucial as it is proven that learners will learn more if they participate more. Some previous researchers have concerns about issues related to learners' participation in terms of relation to the size of the class (Abdullah, Abu Bakar, and Mabob, 2012), the role of learning methods (Debele and Kelbisa, 2017), and action plan (Gonzalez-Cuevas, Rubio, Hernando, Alvarez, and Tavera, 2017). Concerning the participation, Larsen-Freeman and Anderson (2010) underline that the teachers need to have both clear language objectives and content learning objectives for their lesson. These can help learners understand subject matter texts and learn to use the academic language associated with the subject. Oliviera (2015) mentions that there are four steps the teacher of language can follow: setting goals based on key concepts, selecting texts and images to work with learners, analyzing the texts, and planning instruction for the English language learners. Lotan (2008) argues that learners will improve their language skills and learn content when they are given challenging tasks and use English actively in meaningful situations.

Previous researches on collaborative learning reveal that the strategy has positive impacts on learners. Baines, Blatchford, and Kutnik (2008) mention that the benefits of group work include more active participation, sustained engagement in group activities, more connectedness within the group, and higher-order, inferential forms of reasoning. For this reason, teachers should be aware to provide optimal learning opportunities. King (2008) underlines that cooperative activities offer cognitively advanced goals for learners to achieve a deeper understanding of the material, construct knowledge, solve problems that have more than one answer, create something original, or make a sophisticated decision. It can promote interaction for higher-order thinking activities and will result in complex learning.

Scrivener (2011) states that learners need to have more interaction with their classmates to obtain more benefits. To achieve the goal, teachers need to create activities focusing more on students and students' interaction. Stevens (2008) argues that engaging in collaborative learning can increase achievement through interaction in a social learning environment. The way of learning also changes the goal structure in the classroom to focus on improvement, resulting in 
positive motivation for all learners. Finally, the learning processes take advantage of the peer orientation of adolescents by constructing a classroom structure when learners encourage and support one another in academic work.

Gillies (2008) states that collaborative activities are ideal for implementing in the classroom to stimulate learners' interest through interaction with their peers and improve participation and engaged in more useful activities. The success, as Ur (1992) mentioned, depends on the surrounding social climate, how to habituate the class, and the selection of an interesting and stimulating task whose performance is well within the ability of the group. Furthermore, Gillies (2016) underlines that the key to success depends on teachers in establishing collaborative learning. Moreover, teachers must identify an effective collaborative learning strategy with attention to positive interdependence, face-to-face interaction, individual accountability, group processing, and social skills (Adams, 2013). There is a significant impact for learners because it can improve students' achievement (Slavin, 1982; Adams, 2013; Tran, 2014; Gull and Sehzad, 2015).

Collaborative learning gives room for students to be more active. It also allows students to engage in critical thinking activities. In this situation, higher-order thinking skills are necessary. Johnson (2002) argues that higher-order thinking makes use of critical thinking and creative thinking. Critical thinking is an organized process involving mental activities as problem-solving, decision making, persuading, analyzing assumptions, and scientific inquiry. Meanwhile, creative thinking is a mental activity that deals with originality and insight. By thinking creatively and critically, learners can deal with problems systematically, to meet myriad challenges in an organized manner, to formulate innovative questions and design original solutions.

\section{Intensive English Program at Universitas Islam Negeri Malang (UIN)}

The aim of Intensive English program of General English is to equip learners to practice English actively. This program is managed and organized by the English Language Center (ELC) of UIN Malang. Learners from Non-English department are required to take this program to improve their mastery of English. The learners taking this program are those from the third semester. This program is managed in the evening after learners complete regular classes. Learners learn general topics that have been offered by the ELC. These topics are selected and adapted by the academic team of the ELC. In the learning process, the instructors are responsible for facilitating learning activities using chosen topics. They are permanent and non-permanent lecturers and have graduated from a master's degree in English. Although the primary concern of the program is on listening and speaking, other skills, namely reading and writing, are also encouraged.

\section{Considerations for Classroom Action Research}

The need for the research was identified due to low participation in the first-class session of a new semester. In the meeting, the researchers presented a course overview. Students were encouraged to give responses to the lecture. The researchers also gave questions related to the content of the first session. These were all about learners understanding about the course outline for topics that learners would work on, learners' knowledge about the teaching contract, learners' expectations in the semester, and learners' opinions about learning English in terms of difficulty, solution of learning problems, and benefits of learning English. In addition, the researchers wanted to know learners' mastery of English. Learners were encouraged to tell their experience in learning English. In general, the students showed only limited responses. All the learners responded well to the questions which required them to answer in a single short sentence, such as "Is it important for us to study English?" and "do you want to improve your English?" However, when questions required them to give a longer answer, such as "why is it important to study English?", they did not respond automatically. Sometimes, there was a long silence until the 
lecturer repeated the questions several times. Only a few number of students sometimes raised their hands; willing to give responses to our questions.

This initial impression then led us to investigate more about the barriers why learners in our class did not actively participate. Although we firmly believe that teachers' factors in terms of characteristics and creativity do make sense in making learners comfortable, it does not always meaningful for them. Using humor, for example, to make learners alert and comfortable, does not always mean that learners' participation will improve as well as their mastery in English. The important thing was that learners involve actively through practicing English skills that would make them proficient in using the language. For that reason, we focused on the causes that hinder learners from participating and practicing the language. Through observation, we identified some factors which caused low participation. The first factor was the size of the class and the traditional seating arrangement. With thirty-five learners in the classroom, it was not ideal for teaching language skills. The second factor to be considered as the cause of low participation was the decrease in learners' energy. Learners studied from morning to afternoon, and the classes for General English started after learners finish their regular courses. The third factor was that learners had different levels of proficiency in English, making some learners quite active, and the rest were not. Another factor that made them less active was related to the confidence level. Some of them were confident to give responses in the class while the majority were not.

To engage students in active participation, we needed to make changes in managing the class interaction among learners. According to Scrivener (2011), teachers should consider seating positions that enable learners to learn in their classroom optimally. To switch from a teachercentered style, we need to arrange the chairs which can accommodate learners for more participation; namely, the group works for collaborative activities. In terms of students' low energy for learning in the evening, collaborative works activities are relevant as the learners can share the jobs for completing the works.

Regarding the level of proficiency, learners work in groups with different levels of ability so that they can help each other. Working in a group can also reduce anxiety for those who are less confident to speak with their teachers. Learners would feel more comfortable with making mistakes when they communicated with their classmates. It surely would encourage them to speak more.

It is clear then that low participation in the classroom would risk the quality of the learning process in the classroom. The efforts to solve the problem were necessary. Because of that, this classroom action research aims to improve the quality of learning in the class. The researchers expect that this practical experience would encourage other researchers to have action research in their classes.

The objective of the research is to study the roles of collaborative works dealing with learners' participation in the teaching and learning process in the classroom.

To be specific, the research focuses on:

1. How learners in class are

2. What collaborative activities applied in the class are

3. How learners behave in collaborative learning 


\section{METHOD}

\section{Respondents}

There were thirty-five third semester learners of the Accounting Department, UIN Maulana Malik Ibrahim Malang, involved in the study. All of the learners had to take a course on General English with a focus on listening and speaking. Because of that reason, the curriculum aimed to integrate at least two skills in English, namely, listening and speaking.

\section{Method of Study}

The possible action to improve classroom activities is Classroom Action Research (CAR). This research should be initiated by the teachers in the class to make some improvements in the way of teaching, leading to improvement in certain aspects of learning. Burns (2010) states that CAR is a reflective practice, and the teacher is a researcher. One of the main aims of this action is to identify the problematic situation or issues, intervene in it, and bring the changes or improvements in practice. The method of action research used was one proposed by Kemmis, McTaggart, and Nixon (2014). It comprises cycles; planning, acting and observing, and reflecting.

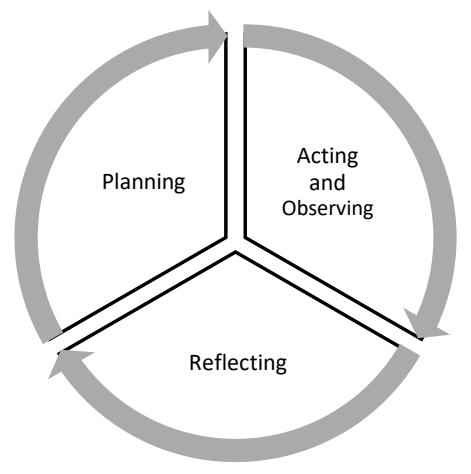

Kemmis, McTaggart, and Nixon model of Action Research

\section{Instruments}

\section{Observation}

For the teacher-researcher, the observation is essential to gather data directly upon classroom interactions and events. Burns (1999) underlines that observing learners' behavior and actions need regular and conscious notice as well as a more systematic and precise procedure. Ideally, observation needs to involve learners' behavior and actions. They include a focus for the observation, which is relevant to the group's research, identification of physical location, the object of observation whether group or individual, events recording, objectivity and preciseness to the observation, a complete recording of events or incidents, and appropriate system of recording the event.

In the target class, the learners' activities are observed since collaborative learning is implemented in the classroom. It involves activities from the very start, such as establishing a group, the discussions, the process of making something, the distribution of activities, and the presentation of the result. 


\section{Data Collection}

In gathering data, the teacher-researchers observed student behavior and incident during the learning process. The process of observation took place for several class sessions. It aimed to make sure that the techniques and the learning activities as a reflection of success were achieved. The collection of data started from the beginning until the end of the program.

\section{Data Analysis}

The techniques used for analyzing the data are qualitative. The data from observation would give information about the process, including problems, solutions, the sequence of the events, and other essential activities in the teaching and learning process.

\section{RESULTS AND DISCUSSION}

\section{Result}

\section{- Planning}

The problem existing in the classroom was low participation among learners. To address the issue, we prepared strategies and treatments for making changes in the way of learners' learning. The first plan was to group the learners in collaborative activities. The following meetings were in the form of collaborative works. The class was supposed to divide into several groups, and learners complete the assigned tasks in listening and speaking by involving group discussions, group presentations, and class commentary. The learners were monitored and guided by the teachers to make sure that they participated in the assigned activities. Learners were assigned to share their ideas freely and encouraged to divide jobs for completing the assignment. The use of English in every discussion and presentation was also encouraged. However, the use of minimal Indonesian was acceptable if the students did not know how to express it in full English.

In practice, the content subject related to general issues focusing on listening and speaking. The materials to support learning were from various sources; textbooks, videos and reading text from the internet, newspapers, and other available materials. The topics prepared in collaborative learning include objects around our environment, environmental problems, discovery, and other social issues.

\section{- Acting and Observing}

The following table shows the main activities in the first-class session of the implementation of collaborative works.

Table 1 Topic and activities in the first class session of collaborative learning

\begin{tabular}{ccl}
\hline Content/Topic & \multicolumn{1}{c}{ Collaborative Activities } \\
\hline & - & Learners listened to the audio and shared responses \\
& - & $\begin{array}{l}\text { Each group conducted a mini-research project: finding problems in the } \\
\text { environment, making arguments, and proposing solutions for the } \\
\text { problems }\end{array}$ \\
Environmental & \\
Problems & - & The results were written on a large paper and were presented to the \\
& class \\
& & Learners participated in questions and answers. \\
\hline
\end{tabular}


The content of the lesson was related to Environment. Learners were required to listen to a newscast audio about taking care of the garbage in a small city. The learners filled in the missing parts of the text and shared answers. They then had a task to make a list of objects that people could recycle. They listed the things they considered able to recycle and shared those with other group members.

The following activity was a mini-research project. This project required learners to explore their classroom and identified a specific problem they encountered in the classroom. They shared the result of the project in front of the class. The results were written on a piece of A3 full paper and were displayed on the wall. Each member of the group had a turn to present the results to all learners in the class. Learners made questions and answers to know the project in detail.

Through observation, learners carried various issues related to their classroom. These included the cleanliness of the floor, the wall color, the size of the classroom, the chairs and tables, the blower malfunction, the LCD, etc. They made a judgment about the situation, gave some opinions to the problem, and offered suggestions on improving the quality of the classroom.

The main points in these activities were learners tried to use their analytical thinking, analyzing the condition of the classroom, and making a judgment based on what they saw. They also thought about the solutions to the problems in the environment. The activities encouraged learners to think, evaluate, and create ideas for making the situation better.

In the end, they committed to making a schedule for cleaning their classroom before the class started.

Table 2 Topic and activities in the second session of collaborative learning

\begin{tabular}{ccl}
\hline Content/Topic & \multicolumn{1}{c}{ Activities } \\
\hline & - & $\begin{array}{l}\text { Learners listened to the audio on a topic related to discovery and shared } \\
\text { responses. }\end{array}$ \\
Discovery: Future & - & $\begin{array}{l}\text { Each group designed a car prototype on an A3 paper and displayed it on } \\
\text { the wall. }\end{array}$ \\
Transportation & $\begin{array}{l}\text { Learners visited each display and asked the owner of the design for } \\
\text { information. }\end{array}$ \\
\hline
\end{tabular}

The content of the lesson related to discovery. Learners got information about traffic jams and the effects. They also worked in an assigned group and designed a prototype car that was thought able to solve traffic jams in the future by using papers and color markers that had been provided.

When all groups finished their drawing, they put it in front of the class. They explained their drawing to other learners. Learners actively participated by asking and responding. The car models that look unique attracted them to ask questions.

Table 3 Topic and activities in the third session of collaborative learning

\begin{tabular}{|c|c|}
\hline Content/Topic & Activities \\
\hline $\begin{array}{l}\text { Discovery: Making } \\
\text { Unique Creature }\end{array}$ & $\begin{array}{l}\text { - Learners designed paper clothes made of newspapers and used color } \\
\text { pens, scissors, cutters, glue. } \\
\text { - Learners discussed in English during the making process, and they } \\
\text { presented the result in front of the class. }\end{array}$ \\
\hline
\end{tabular}

The topic of the lesson was the discovery report. Learners listened to an audio-report on the discovery of an engine. They answered the questions related to the report. In the second 
activity, learners were assigned to make a group of five and were assigned to create discovery in the form of designing a model of the ugly creature. They discussed using English with group members to design a model. Group members chose their representative to be a model of the creature.

To support the activity, the learners used newspapers, glue, colorful markers, cutters, scissors, and other necessary materials. They cut and put the pieces of newspaper to the body of one of learner who was assigned to be the model. When all groups finished their design, they explained the result in front of the class. All learners had an opportunity to give responses.

\section{- Reflecting}

From the planning and acting, it is clear that the plan in the action research met the expectation. We analyze the result of the observation conducted in three consecutive meeting sessions. The first observation in the first session related to the students' participation in the miniresearch project. It was shown that all members took part in observing the classroom environment. They discussed the problems and made a report in a group discussion, and shared the results done collaboratively. Each member of the group had an opportunity to explain a particular part that made all group members were engaged in the activity. Similarly, the second reflection related to learners' actions throughout the activity. All members of the group contributed ideas in designing a prototype of a future car to be accomplished. The result was the final project from the contribution of ideas among group members. The learners displayed the project, and all group members had the opportunity to explain to all learners. In the last observation, the learners also showed their collaboration activities when they involved in designing a paper costume of an ugly creature. They worked in a group, shared ideas, and took responsibilities in explaining the results to all learners in the class.

The data of the three consecutive observations reveal that learners made significant progress in participation while they applied collaborative tasks. It happened when learners got a clear instruction of the task. For the task itself, it was a prepared task that involves group activities. In that way, learners engaged in completing it as they feel responsible as a part of the group. Realizing the result had met the expectation, we felt that the learning process did not need another cycle.

\section{Discussion}

The first step in the cycle, namely planning, was established and fulfilled the criteria proposed in the CAR. We thought about possible treatments and actions intended for some significant changes for learners' participation in the classroom. The plan had been set and ready for implementation.

From the observation in three consecutive meetings, the learners participated more actively compared to their participation before collaborative learning was applied in the classroom. From being passive, they turned to be engaged when they solved problems together in their group. Working in a group in the three sessions needed them to participate more actively. To accomplish the tasks, they needed more interaction among group members. When they interacted with their classmates, they were more confident. It happened because they did the activities with people they knew better. The learners learned how to divide the jobs into their group. They also worked on how to present their works in front of the class. One crucial point was that although the time available was limited, the learners could use the time optimally for doing assigned tasks, and they also could participate more in the classroom.

From the observation, it shows that the responses of the learners on the implementation of collaborative learning in the classroom were positive. It indicated the active participation of learners in the class. Previous research with the similar result was conducted by Herrmann (2013). 
It mentions that collaborative learning makes learners increase their in-class engagement. Another study done by Miller (2017) mentions that learners working in a group were comfortable in asking questions to the other members. This way made them enjoy working in a group.

The activities in collaborative learning also engaged learners to use their thinking skills. By sharing and discussing the assigned tasks, they had the opportunity to think about the issues. It is in line with the study conducted by Gokhale (1995) and Castle Jr. (2014), mentioning that working in a group can improve the thinking process. The way of thinking in this manner is an essential asset for life (Johnson, 2002).

\section{CONCLUSION}

The implementation of collaborative activities in the English classroom has a positive impact on the learning process. One of the benefits is that it can improve the learners' participation in the class. To make collaborative works effective, there are some factors to consider. First, the activities and tasks should be various to maintain learners' interests. Secondly, there are clear procedures and objectives in the implementation of collaborative learning. Third, teachers have the responsibility to be facilitators and motivators in the learning process. By observing and improving collaborative learning continuously, it can give quite significant impacts on the learning process. There are still many aspects that are worth investigating in the teaching and learning process. Therefore, we hope that teachers and teachers-researchers implement strategies through collaborative action research to improve their teaching practices in any aspect of classroom issues.

\section{REFERENCES}

Abdullah, M.Y., Abu Bakar, N. R., and Mabob, M. H. (2012). Student's participation in classroom: what motivates them to speak up? Procedia - Social and Behavioral Sciences $51(202) 516-522$

Adams, A., R. (2013). Cooperative learning effects on the classroom. Unpublished thesis: Northern Michigan University.

Baines E., Blatchford, P., and Kutnik, P. (2008). The teacher's role in implementing cooperative learning in the classroom. In R. M. Gillies, A. Ashman, \& J. Terwel (Eds.), Pupil grouping for learning: Developing a social pedagogy of the classroom (pp. 56-72). New York: Springer.

Burns, A. (1999). Collaborative action research for English language teachers. Cambridge: Cambridge University Press.

Burns, A. (2010). Doing action research in English language teaching. New York: Routledge.

Castle Jr. T.D. (2014). The impact of cooperative learning on the development of need for cognition among first-year college students. Unpublished thesis: The University of Iowa.

Debele, E. T., and Kelbisa, E. M. (2017). The role of active learning methods for classroom participation: the case of first-year students of sociology in Samara University. IOSR Journal of Humanities and Social Science, Vol. 22, Issue 7, 2017.

Gillies, R. M. (2008). The teacher's role in implementing cooperative learning in the classroom. In R. M. Gillies, A. Ashman, \& J. Terwel (Eds.), Teachers' and students'verbal behaviours during cooperative learning (pp. 238-257). New York: Springer Science+Business Media, LLC. 
Gillies, R. M. (2016). Cooperative learning: Review of research and practice. Australian Journal of Teacher Education, 41 (3), 39-54.

Gokhale, A. A. (1995). Collaborative learning enhances critical thinking. Journal of Technology Education, 7 (1), 22-30.

Gonzalez-Cuevas, G., Rubio, M., Hernando, A., Alvarez, M. J., and Tavera, M. V. (2017). Action research plan to boost participation in college students. $3^{\text {rd }}$ International Conference on Higher Education Advances.

Gull, F., and Shehzad, S. (2015). Effects of cooperative learning on students' academic achievement. Journal of Education and Learning, 9 (3), 246-255.

Herrmann, K. J. (2013). The impact of cooperative learning on student engagement: Result from an intervention. Active Learning in Higher Education, 14 (3), 175-187.

Johnson, E.B. (2002). Contextual teaching and learning: What it is and why it's here to stay. Thousand Oak, CA: Corwin Press.

Kemmis, S., McTaggart, R, and Nixon, R. (2014). The action research planner: Doing critical participatory action research. Singapore: Springer.

King, A. (2008). The teacher's role in implementing cooperative learning in the classroom. In R. M. Gillies, A. Ashman, \& J. Terwel (Eds.), Structuring peer interaction to promote higherorder thinking and complex learning in cooperating groups (pp. 73-91). New York: Springer.

Larsen-Freeman, D., and Anderson, M. (2011). Techniques and principles in language teaching; third edition. Oxford: Oxford University Press.

Lotan, R. A. (2008). The teacher's role in implementing cooperative learning in the classroom. In R. M. Gillies, A. Ashman, \& J. Terwel (Eds.), Developing language and mastering content in heterogenous classrooms (pp. 184-200). New York: Springer.

Miller, S. (2017). Group encouragement: Action research on cooperative learning. Retrieved from https://scholarworks.bgsu.edu/honorsprojects/256

Oliveira, L. C. (2015). A language-based approach to content instruction (LACI) for English language learners. Journal of Language and Literacy Education. Retrieved from https://www.google.com/url?sa=t\&source=web\&rct=j\&url=http://jolle.coe.uga.edu/wpcontent/uploads/

Scrivener, J. (2011). Learning teaching, the essential guide to English language teaching; $3^{\text {rd }}$ edition. London: Macmillan education.

Slavin, R. E. (1982). Cooperative learning. USA: National Education Association of the United States.

Stevens, R. J. (2008). The teacher's role in implementing cooperative learning in the classroom. In R. M. Gillies, A. Ashman, \& J. Terwel (Eds.), Cooperative learning and literacy instruction in middle-level education (pp. 92-109). New York: Springer.

Tran, V. D. (2014). The effects of cooperative learning on academic achievement and knowledge retention. International Journal of Higher Education, 3 (2), 131-140. 
Ur, P. (1991). A course in language teaching; Practice and theory. Cambridge: Cambridge University Press. 